DOI:https://doi.org/10.24127/ajpm.v10i4.4281

\title{
THE EFFECT OF ONLINE LEARNING METHODES ON STUDENT'S LEARNING ABILITIES IN STATISTICS COURSE
}

\author{
Zuhri $^{1^{*}}$ \\ ${ }^{1 *}$ Sekolah Tinggi Ilmu Manajemen Sukma, Medan, Indonesia \\ *Corresponding author \\ E-mail: $\quad$ zuhrimuin63@gmail.com ${ }^{1 *}$
}

Received 26 September 2021; Received in revised form 16 November 2021; Accepted 27 December 2021

\begin{abstract}
Online learning is a solution given to overcome the difficulty of direct teaching and learning due to social restrictions in the Covid-19 pandemic. The purpose of this study was determine the effect of online learning on the learning abilities of students at the institute of management science SUKMA Medan in the statistics course. This type of research is quantitative. The data collection technique in this study used research instruments, then the data were analyzed to test the hypothesis that had been determined using simple linear regression analysis techniques. The results of this study indicate that there is a positive influence of online learning on the learning abilities of students at the institute of management science SUKMA Medan in statistics courses by $68 \%$, while the other $38 \%$ are influenced by other factors, such as environmental factors, psychological conditions or factors that are not studied.
\end{abstract}

Keywords:Learning ability; online learning; statistics

\begin{abstract}
Abstrak
Masa Darurat penyebaran Covid 19 mengharuskan lembaga pendidikan untuk melakukan proses pendidikan melalui pembelajaran online/jarak jauh. Penelitian ini bertujuan untuk mengetahui pengaruh pembelajaran online terhadap kemampuan belajar mahasiswa sekolah tinggi ilmu manajemen SUKMA medan pada mata kuliah statistika. Jenis penelitian ini adalah kuantitatif. Teknik pengumpulan data dalam penelitian ini menggunakan instrumen penelitian, kemudian data dianalisis untuk menguji hipotesis yang telah ditentukan dengan menggunakan teknik analisis regresi linier sederhana. Hasil penelitian ini menyatakan bahwa terdapat pengaruh positif pembelajaran online terhadap kemampuan belajar mahasiswa sekolah tinggi ilmu manajemen SUKMA medan pada mata kuliah statistika sebesar 68\%, sedangkan sisanya sebesar 38\% dipengaruhi oleh faktor lain, seperti lingkungan, kondisi psikologis atau faktor -faktor lain yang tidak diteliti.
\end{abstract}

Keywords:Kemampuan Belajar, Pembelajaran Online, Statistika

This is an open access article under the Creative Commons Attribution 4.0 International License

\section{INTRODUCTION}

Online learning is a solution given to overcome the difficulty of direct teaching and learning due to social restrictions in the Covid-19 pandemic (Rahmasari et al., 2020). The purpose of online learning is so that students and students can continue to learn so they don't miss out. In addition, online learning is expected to make it easier for teachers or lecturers to provide material in accordance with the RPS that has been made.

According (Yanti et al., 2020). Online learning is a precise and efficient teaching and learning process using the internet. (Muhammad, 2020) (Prahesti et al., 2021) online learning is an effective learning method, such as practicing with feedback related to combining collaborative activities with independent learning. Google classroom is the most interesting innovation that educators 
and students can use in carrying out learning

According to (Lestari, 2015) interest in learning is an internal drive for a student to improve study habits. Research that has been conducted by (Sijabat et al., 2020) obtained the results that there is an effect of online learning on general interest in learning physics. The results obtained from the research (Kurniawan, 2021) are the effect of online learning methods on student interest in learning by $3.8 \%$. While the research conducted by (Jusmawati et al., 2020) obtained the results that there was an effect of online-based learning on interest in learning mathematics.

From several studies that have been conducted, it can be understood that online learning has a significant influence on students' interest in learning. However, there is no research that discusses the effect of online learning on students' learning abilities, especially in statistics courses. Meanwhile, students' learning ability in mastering the material is one of the objectives of the learning process. Statistics is science to collect, analyze, interpret, and conclude data. This knowledge is widely used in all sectors of work, from banking, education, economics, etc. Statistics course is a mandatory course for management study programs. Therefore, it is necessary to conduct further research on the effect of online learning on students' learning abilities in statistics courses. According to (Sirait, 2016) There is a significant relationship between learning interest and learning ability. This is in line with research (Nurhasanah \& Sobandi, 2016) which concludes that students' learning abilities can be improved by increasing student interest in learning. so in this study, the variable of interest in learning was replaced with the variable of student learning ability. This study aims to see how far the influence of online learning on students' learning abilities in statistics courses

\section{METHOD}

This research is quantitative research. it means that the research was conducted by collecting measurable data using statistical techniques to determine the effect of online learning models on students' learning abilities in statistics courses.

Quantitative data in this study con1sisted of data taken through the distribution of closed questionnaires and tests given to students. This research was conducted by applying online learning in statistics courses at the Management study program at the Sukma College of Management, Medanclass 5A, 5B 5C and 5D.

The subjects in this study were level 3 students of management studies program from Sukma College of Management, Medan. The location of this research was carried out at the Sukma College of Management, Medan. Sakti Lubis Sitirejo II, Medan City, North Sumatra.

The population used in this study was 92 fifth-semester students from 4 classes of management study programs at the Sukma College of Management, Medan. The total population in this study was 92 so the sampling technique in this study used the total sampling method. Its means total sample in this study is 92 .

The first stage of this research is observations was made to observe the learning abilities of the students who were the samples of this research in the statistics course that had been taught through the application of online learning methods, then a test was given 3 times in stages to the sample, namely 
the first test was carried out at the $5^{\text {th }}$ $10^{\text {th }}$ meeting and last at the $15^{\text {th }}$ meeting. The next research stage is the distribution of questionnaires via goggle form to determine the motivation and enthusiasm of students in participating in online learning. The questionnaire uses liker scale with 4 alternative an- swers on each instrument, namely always, often, sometimes, and never.

The variables in this study include independent variables and dependent variables. The independent variable is online learning (X1) with 4 indicators. The indicators for independent variable are presented in Table 1.

Tabel 1 Variable Indicator

\begin{tabular}{|c|c|}
\hline Variable & Indikator \\
\hline \multirow{5}{*}{ Online Learning $\left(\mathrm{X}_{1}\right)$} & 1. student response \\
\hline & 2. understanding of statistics courses \\
\hline & 3. the effectiveness of using the google classroom \\
\hline & $\begin{array}{l}\text { application and whatsapp group in statistics } \\
\text { courses }\end{array}$ \\
\hline & 4. visual interaction in statistics course \\
\hline
\end{tabular}

The dependent variable of this study is the ability to learn statistics (Y) with 5 indicators. The statistical learning ability test instrument consists of 15 questions. Each indicator is represented by 3 questions. The indicators for dependen variable are presented in Table 2.

Table 2. Indicators of test questions

\begin{tabular}{lll}
\hline \multicolumn{2}{c}{ Variabel } & \multicolumn{1}{c}{ Indikator } \\
\hline Student's & learning & a. Students' understanding of the data description. \\
ability (Y) & b. The ability of students in organizing data. \\
& c. The ability of students in presenting data. \\
& d. The ability of students in analyzing data. \\
& e. Students' ability in interpreting data \\
\hline
\end{tabular}

After testing students' abilities and distributing questionnaires, the measured values were collected as data for analysis. the data that has been collected is tested for validity and reliability. Validity test aims to determine the validity of the measuring instrument used. While the reliability test was carried out to determine the stability of the measuring instrument (Sumargo, 2020).

Validity test is carried out using the formula bivariate person correlation using the SPSS application. If the correlation probability is less than or less than 0.05 , then it is declared valid and if the correlation probability result is greater than 0.05 , it is declared invalid (Potu, 2013).

Test Cronbach Alpha reliability test with SPSS by looking at the following provisions. If the value of Cronbach's alpha $>0.60$; then the questionnaire is declared reliable / consistent if the value of Cronbach's alpha $<0.60$; then the questionnaire is declared unreliable / consistent.

\section{Normality Test Linearity Test}

The normality test with the one sample Kolmogrov Smirnov test is 
determined by comparing significance value (sig) with alpha, if the sig value > alpha $(0.05)$ then the research data is normally distributed, whereas if the sig value < alpha (0.05), the research data is not distributed normal.

In the SPSS calculation, if the significant value from linearity is > 0.05 , then there is a linear relationship between the independent and dependent variables. If the significant value of deviation from linearity is $<0.05$, then there is no linear relationship between the independent and dependent variables.

The next stage is a documentation technique, which is taking the final score of the student statistics course as an illustration of the student's ability to master the subject. In the preparation of this study, a quantitative method with an associative approach was used, namely research that sought a causal relationship between the independent variable (X) and the dependent variable (Y) using a hypothesis. The variables in this study include independent variables and dependent variables. The independent variable in this study is online learning (X) while the dependent variable is learning ability $(\mathrm{Y})$.

Hypothesis testing is done by using a simple regression analysis model to test the variable $(\mathrm{X})$ against the variable $(\mathrm{Y})$. The hypotheses in this study are 1$)$

$\mathrm{H}_{0}:$ here is no effect of online learning $(\mathrm{X})$ on learning ability $(\mathrm{Y})$.

$\mathrm{H}_{1}$ : There is an effect of online learning $(\mathrm{X})$ on learning ability (Y).

According to(Suyono, 2015) the." form of a simple linear regression model is

$$
Y=\beta_{0}+\beta_{1} x+\varepsilon
$$

Where $\mathrm{X}$ is the independent variable, $\mathrm{Y}$ is the dependent variable, 1 is the parameters whose values are unknown, where $\beta$ is the random error or $\varepsilon$ called the regression coefficient, and (random error). Data processing in this study the author uses SPSS software, then from the results of data analysis, a conclusion is drawn.

\section{RESULTS AND DISCUSSION}

The first stage of this research is observation is done to observe the learning ability of students who are the research sample in statistics courses taught through online learning methods. Online learning methods in this study was applied using goggle classroom and what sap group. In goggle class room, the lecturer can provide written material in the form of an adobe reader and there is also an explanation video about the material provided. Online lectures were held for 16 meetings through google classroom according to a predetermined schedule. Furthermore, students who want to ask about the lecture material then the discussion is continued via what sap group.

The goal is that students can more easily understand the material in statistics courses and it is hoped that students will also have the ability to study statistics. To measure the student's learning ability in the statistics course, a test was given via goggle form for 3 times, namely at the $5^{\text {th }} 10^{\text {th }}$ and $15^{\text {th }}$ meetings. Furthermore, to observe the efficiency of online learning, questionnaires were distributed via goggle form. The goggle form link is shared via what sap group. The questionnaire uses liker scale with 4 alternative answers on each instrument, namely always, often, sometimes, and never. From the results of this study, it can collect data from a questionnaire filled out 
by 92 students who have been determined as samples. Then the data is processed using SPSS to test the validity, reliability test and multiple linear regression test.

\section{Validity test}

Each statement item on the questionnaire was tested for validity using SPSS and the results are presented in

Table 3.

Table 3. The validity of online learning (X)

\begin{tabular}{|c|c|c|c|c|c|}
\hline Variable & Indicator & $\begin{array}{c}\text { Statement } \\
\text { number }\end{array}$ & $\begin{array}{c}\text { Corelation } \\
\text { value }\end{array}$ & $\begin{array}{l}\text { Correlation } \\
\text { Probability }\end{array}$ & Description \\
\hline \multirow{9}{*}{$\begin{array}{l}\text { Online } \\
\text { Learning } \\
\text { (X) }\end{array}$} & a. Student response & 1 & 0,671 & 0,000 & Valid \\
\hline & & 2 & 0,761 & 0.000 & Valid \\
\hline & b. Understanding of & 3 & 0,690 & 0,000 & Valid \\
\hline & statistics courses & 4 & 0,675 & 0,000 & Valid \\
\hline & c. the effectiveness of & & & & \\
\hline & classroom & 5 & 0,714 & 0,000 & Valid \\
\hline & $\begin{array}{l}\text { application and } \\
\text { whatsapp group in } \\
\text { statistics courses }\end{array}$ & 6 & 0,725 & 0,000 & Valid \\
\hline & d. visual interaction & 7 & 0.691 & 0,000 & Valid \\
\hline & in statistics course & 8 & 0,689 & 0,000 & Valid \\
\hline
\end{tabular}

Table 3 shows the results of the validity test of variable i online learning (X) variable which consists of 4 indicators, and each indicator has 2 statement items. From Table 3 it is found that statements 1 to 8 are valid because the correlation probability is smaller than 0.05. Furthermore, each item tested on students to measure students' learning ability towards statistics courses, is also tested for validity and is presented in Table 4 .

Table 4. The validity of student's learning ability (Y)

\begin{tabular}{|c|c|c|c|c|c|}
\hline Variable & Indicator & $\begin{array}{l}\text { Statement } \\
\text { number }\end{array}$ & $\begin{array}{l}\text { Corelation } \\
\text { value }\end{array}$ & $\begin{array}{l}\text { Correlation } \\
\text { Probability } \\
\end{array}$ & Description \\
\hline \multirow{10}{*}{$\begin{array}{l}\text { student's } \\
\text { learning } \\
\text { ability } \\
\text { (Y) }\end{array}$} & \multirow{2}{*}{$\begin{array}{l}\text { a. Students' understanding of } \\
\text { the data description }\end{array}$} & 1 & 0,671 & 0,000 & Valid \\
\hline & & 2 & 0,761 & 0.000 & Valid \\
\hline & \multirow{2}{*}{$\begin{array}{l}\text { b. The ability of students in } \\
\text { organizing data. }\end{array}$} & 3 & 0,690 & 0,000 & Valid \\
\hline & & 4 & 0,675 & 0,000 & Valid \\
\hline & \multirow{2}{*}{$\begin{array}{l}\text { c. The ability of students in } \\
\text { presenting data. }\end{array}$} & 5 & 0,714 & 0,000 & Valid \\
\hline & & 6 & 0,725 & 0,000 & Valid \\
\hline & \multirow{2}{*}{$\begin{array}{l}\text { d. The ability of students in } \\
\text { analyzing data. }\end{array}$} & 7 & 0.691 & 0,000 & Valid \\
\hline & & 8 & 0,689 & 0,000 & Valid \\
\hline & e.Students' ability & 9 & 0,671 & 0,000 & Valid \\
\hline & interpreting data & 10 & 0,761 & 0,000 & Valid \\
\hline
\end{tabular}

Table 4 shows the results of the validity test of students' learning ability (Y) in statistics courses. Variable which consists of 5 indicators and each indicator has 2 statement items. From Table 4 it is Thefound that statements 1 to 10 are valid because the correlation probability is smaller than 0.05 , 
Because each item from independent variable and dependent variable items were declared valid, then continued with the reliability test. If the value of Cronbach's Alpha is obtained > 0.70, that instrument is said to be reliable (Hidayat, 2021). The results of the reliability test of the independent and dependent variables are presented in Table 5 .

Table 5. The results of the reliability test

\begin{tabular}{llll}
\hline Variable & $\begin{array}{l}\text { Total } \\
\text { items }\end{array}$ & $\begin{array}{l}\text { Cronbach's } \\
\text { Alpha }\end{array}$ & Description \\
\hline $\begin{array}{l}\text { Online } \\
\text { Learning }\end{array}$ & 8 & 0,839 & Reliable \\
$\left(\mathrm{X}_{1}\right)$ & & & \\
$\begin{array}{l}\text { Student's } \\
\text { learning } \\
\text { ability (Y) }\end{array}$ & 0,848 & Reliable \\
\hline
\end{tabular}

In Table 5, the results of the reliability test show that online Learning (X1), and Student's learning ability (Y) obtained Cronbach's Alpha results > 0.70 so that both variables are reliable.

\section{Normality and linearity test}

Then, a prerequisite test was carried out by performing a normality test and a linearity test, the results of the normality test showing the Asymp value Sig. (2-tailed) of $0.855>0.05$, this means that the data is normally distributed, then the linearity test is carried out from the SPSS calculation results.

Deviation from Linearity shows a sig value of $0.625>0.05$, this indicates that there is a linear relationship between the independent and dependent variables. The instrument test and prerequisite test have been met, then the hypothesis is tested using simple linear regression analysis. The test results of simple linear regression analysis are presented in Table 8.

Table 8. Summary of regression test results.

\begin{tabular}{llllll}
\hline & \multicolumn{2}{l}{$\begin{array}{l}\text { Unstandadi } \\
\text { zed } \\
\text { Model }\end{array}$} & $\begin{array}{l}\text { Standardi } \\
\text { zied } \\
\text { Coefficients } \\
\text { Coeficien } \\
\text { ts }\end{array}$ & \multicolumn{1}{c}{$\mathrm{T}$} & Sig \\
\cline { 2 - 4 } & $\mathrm{B}$ & $\begin{array}{l}\text { Std. } \\
\text { Eror }\end{array}$ & \multicolumn{1}{c}{$\beta$} & & \\
\hline Const & 8.0 & 3.33 & & 2.41 & .01 \\
ant & 55 & 1 & & 8 & 7 \\
$\mathrm{X}$ & .73 & .055 & .788 & 13.3 & .00 \\
& 2 & & & 48 & 0 \\
\hline
\end{tabular}

The simple regression test hypothesis is as follows:

$\mathrm{H}_{0}$ : Tthere is no effect of online learning $(\mathrm{X})$ on learning ability (Y)

$\mathrm{H}_{1}$ : There is an effect of online learning $(\mathrm{X})$ on learning ability (Y)

Hypothesis testing is tested by comparing the significant value of $\mathrm{t}$ with an alpha of 0.05 , according to (Suyanto 2011) if Significant $t<0.005$, $\mathrm{HO}=$ rejected, otherwise Significant $\mathrm{t}>$ 0.005 . Based on table 8 , it is known that the significance value (sig) is 0.017 $<0.05$, so it can be concluded that $\mathrm{H} 0$ is rejected and $\mathrm{H} 1$, This means that there is a significant influence between online learning $(\mathrm{X})$ on student learning ability $(\mathrm{Y})$ in the statistics course.

From the table 8, it can be seen that the regression equation obtained is

$$
Y=8,055+0,732 x+\varepsilon
$$

From model regression 2 showed that the constant value $(\alpha)=$ 8.055 , this number indicates that if there is no online learning $(\mathrm{X})$ then the consistent value of student's learning ability in statistics course (Y) is 8.055. Its mean the student's learning ability in statistics course (Y) influenced by other variables outside of this study is 8.055.

The regression coefficient $\left(\beta_{1}\right)=$ 0.732 is the directional coefficient of the online learning variable $(\mathrm{X})$ that afects students' learning abilities in sta- 
tistics $(\mathrm{Y})$. Its meaning that for every $1 \%$ addition of online learning $(\mathrm{X})$, students' learning abilities in statistics (Y) will increase by 0.732 . From the data analysis shows the regression coefficient value is positive, it can be said that online learning $(\mathrm{X})$ has a positive effect on students' learning abilities in statistics course $(\mathrm{Y})$.
The magnitude of the relationship between online learning variables and student learning abilities in statistics courses which can be explained by the regression equation model 2 can be seen from the summary Table 9 of regression analysis.

Table 9. Summary of model regression analysis

\begin{tabular}{llllll}
\hline Model & $\mathrm{R}$ & R Square & Adjusted Rsquare & $\begin{array}{l}\text { Std.Error } \\
\text { estimate }\end{array}$ & of the \\
\hline .788 & .620 & .617 & 5.63658 & \\
\hline
\end{tabular}

Based on the Table 9 Summary of the regression analysis model, it can be seen that the relationship between online learning variables $(\mathrm{X})$ and learning ability $(\mathrm{Y})$ is 0.788 which is indicated by the value of $R=0.788$. The value of R square is in table 9 .

The summary of model regression analysis shows 0.620 or $62 \%$, it means that independent variables (X) are labeled to explain dependent variables $(\mathrm{Y})$ by $62 \%$ and the remaining $38.0 \%$ are determined or explained by other variables that do not examine them. Or it can be explained that the magnitude of the influence of online learning methods $(\mathrm{X})$ on learning ability $(\mathrm{Y})$ is $62 \%$ while the remaining $38 \%$ of variables are influenced by other variables outside the study. The results showed that the magnitude of the effect of online learning (X1) on the ability to study statistics courses (Y) was 0.732 . This means that students' learning abilities in statistics courses $(\mathrm{Y})$ tend to be positive. The R-square value of 0.620 means that online learning (X1) has an influence of $62 \%$ on the ability to study statistical subjects $(\mathrm{Y})$, while the remaining $38 \%$ is influenced by variables outside of this study. This means that the regression equation model 2 is able to explain the distribution of data by $62 \%$.

The results of this study indicate that the effect of online learning $(\mathrm{X})$ on students' learning abilities in statistics course $(\mathrm{Y})$ is 0.732 . The research can be interpreted that online learning has a positive effect on students' learning abilities in statistics courses. This is because the statistical material provided through Google Classroom can be accessed anytime and anywhere without a certain time limit, so that students master statistics material via online learning rather than classical learning models. This is in line with the results of research conducted by (Sulistyowaty \& Firdaus, 2020) that the advantage of online learning is that learning or lectures can run well, as expected, practical so that lectures can be carried out flexibly

Some difficulties in carrying out online learning to students including the data quota that is absorbed are larger, must have a stable internet network, so students who are outside the reach of the internet will have difficulty following the online learning process. The difficulties found in this study are in line with the results of research (Habib et al., 2021) which show that the obstacles 
experienced in online learning are internet connection problems and student quotas.

Several previous studies that are in line with the results of this study are: (Jusmawati et al., 2020) "with the results of existing research the effect of online-based learning on the mathematics learning ability of the Megarezky University." (Jamil \& Aprilisanda, 2020) " that online lectures have a significant effect on student learning abilities." and research conducted by (Yunitasari \& Hanifah, 2020)" that online learning during the covid-19 pandemic greatly affects students' learning ability".

The impact of this research is that it can prove that online learning methods have a positive effect on improving students' learning abilities in statistics courses. So that online learning methods can still be considered to continue to be used in the statistics learning process.

\section{CONCLUSION AND SUGGESTION}

From the results of research on the effect of online learning on the learning ability of STIM Sukma students, it can be concluded that there is a significant influence between online learning on the learning ability of Sukma STIM students, by $62 \%$. While $38 \%$ were influenced by other factors, both environmental factors, psychological conditions and other things that were not studied.

Suggestions for further research is that this research is expected to be a reference for further researchers related to online learning methods.

\section{REFERENCE}

Habib, M., Sulistyowati, E., Rohmah, S. N., \& Haryadi, A. R. (2021). Pengaruh Covid-19 terhadap Minat
Belajar Daring Mahasiswa. JISIP (Jurnal Ilmu Sosial Dan Pendidikan), 5(2). https://doi.org/10.36312/JISIP.V5I 2.2014

Hidayat, A. A. (2021). Menyusun instrumen Penelitian \& Uji Validasi Reabiltas. In Health Books Publishing. https://www.google.co.id/books/ed ition/Menyusun_Instrumen_Penelit ian_Uji_Validi/OdAeEAAAQBAJ? $\mathrm{hl}=\mathrm{id} \& \mathrm{gbpv}=1$

Jamil, S. H., \& Aprilisanda, I. D. (2020). Pengaruh Pembelajaran Daring Terhadap Minat Belajar Mahasiswa Pada Masa Pandemik Covid-19. Behavioral Accounting Journal, 3(1), 37-46. https://doi.org/10.33005/baj.v3i1.5 7

Jusmawati, J., Satriawati, S., \& Sabilah, B. (2020). Pengaruh Pembelajaran Berbasis Daring Terhadap Minat. Jurnal Kajian Pendidikan Dasar, 5(2), 106-111.

Kurniawan, D. E. M. (2021). Pengaruh Metode Pembelajaran Daring Terhadap Minat Belajar Mahasiswa di Masa Pandemi Covid-19. Journal Education and Development, 9(2), 47-51. https://doi.org/10.37081/ED.V9I2. 2442

Muhammad, I. (2020). Pengaruh Perkuliahan Daring Terhadap Kemandirian Belajar Mahasiswa Prodi Pendidikan Matematika Universitas Malikussaleh. Jurnal Ilmiah Pendidikan Matematika $\mathrm{Al}$ Qalasadi, 4, 24-30. https://doi.org/10.32505/qalasadi.v 4i1.1567

Nurhasanah, S., \& Sobandi, A. (2016). Minat Belajar Sebagai Determinan Hasil Belajar Siswa. Jurnal Pendidikan Manajemen 
DOI:https://doi.org/10.24127/ajpm.v10i4.4281

Perkantoran, $1(1), \quad 128$. https://doi.org/10.17509/jpm.v1i1. 3264

Potu, A. (2013). Kepemimpinan, Motivasi, Dan Lingkungan Kerja Pengaruhnya Terhadap Kinerja Karyawan Pada Kanwil Ditjen Kekayaan Negara Suluttenggo Dan Maluku Utara Di Manado. Jurnal Riset Ekonomi, Manajemen, Bisnis Dan Akuntansi, 1(4), 1208-1218. https://doi.org/10.35794/emba.v1i4 .2894

Prahesti, T. S., Setyoningrum, A., Fani, R., \& Uci, Z. (2021). Pengaruh Media Pembelajaran Online Terhadap Hasil Belajar Siswa Pada Masa Pandemi Covid-19. Gammath: Jurnal Ilmiah Program Studi Pendidikan Matematika, 6(1), 40-46. https://doi.org/10.32528/gammath. v6i1.5396

Rahmasari, A. F., Setiawan, F., \& Meirza Nanda Faradita. (2020). Pengaruh Pembelajaran Online Terhadap Kemandirian Belajar Siswa Kelas II SD Muhammadiyah 17 Surabaya di Tengah Pandemi Covid-19. INVENTA, 4(2), 158168.

https://doi.org/10.36456/inventa.4. 2.a2609

Sijabat, A., Sianipar, H. F., \& Siahaan, T. M. (2020). Pengaruh Pembelajaran Daring Terhadap Minat Belajar Mahasiswa Pendidikan Fisika Uhkbpnp Pada Matakuliah Fisika Umum. The 2st National Conference on
Education, Social Science, and Humaniora, 84-88.

Sirait, E. D. (2016). Pengaruh Minat Belajar Terhadap Prestasi Belajar Matematika. Formatif: Jurnal Ilmiah Pendidikan MIPA, 6(1), 35-43.

https://doi.org/10.30998/formatif.v $6 \mathrm{i} 1.750$

Sulistyowaty, R. K., \& Firdaus, F. (2020). Penerapan Google Classroom Dalam Pembelajaran Matematika Jarak Jauh Untuk Meningkatkan Keaktifan Belajar Siswa. Lentera Sriwijaya: Jurnal Ilmiah Pendidikan Matematika, 2(2), 14-24. https://doi.org/10.36706/jls.v2i2.12 734

Sumargo, B. (2020). Teknik Sampling (1st ed.). UNJ Press.

Suyono. (2015). Analisis Regresi untuk Penelitian (pp. 1-294).

Yanti, M., Yanti, M. T., Kuntarto, E., \& Kurniawan, A. R. (2020). Pemanfaatan Portal Rumah Belajar Kemendikbud Sebagai Model Pembelajaran Daring Di Sekolah Dasar. Jurnal Pendidikan Dasar, 5(1), 61-68. https://doi.org/10.25078/aw.v5i1.1 306

Yunitasari, R., \& Hanifah, U. (2020). Pengaruh Pembelajaran Daring terhadap Minat Belajar Siswa pada Masa COVID 19. Edukatif: Jurnal Ilmu Pendidikan, 2(3), 232-243. https://doi.org/10.31004/edukatif.v $2 \mathrm{i} 3.142$ 